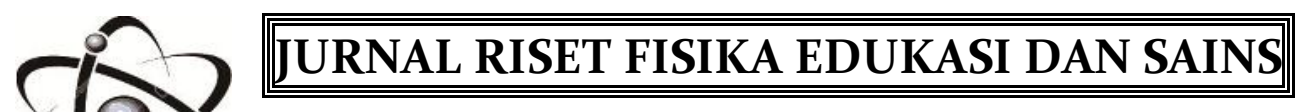

Education and Science Physics Journal

E- ISSN : 2503-3425

P- ISSN : 2407-3563

JRFES Vol 1, No 1 (2014) 1-8

http://ejournal.stkip-pgri-sumbar.ac.id/index.php/JRFES

\title{
PENGEMBANGAN HANDOUT FISIKA DASAR BERBASIS KONSTRUKTIVITAS PADA MATERI DINAMIKA
}

\author{
Silvi Yulia Sari ${ }^{1}$, Nursyahra ${ }^{2}$, dan Husna ${ }^{3}$ \\ ${ }^{1}$ Jurusan Fisika FMIPA UniversitasNegeri Padang, Padang \\ ${ }^{2}$ Program Studi Pendidikan Biologi, STKIP PGRI Sumatera Barat \\ ${ }^{3}$ Program Studi Pendidikan Fisika, STKIP PGRI Sumatera Barat \\ Emailssilvi_yuri@yahoo.com \\ http://dx.doi.org/10.22202/jrfes.2014.v1i1.1180
}

\begin{abstract}
The availability of teaching materials for the course Physics to support the creation of an effective and interactive learning in STKIP PGRI felt still lacking. Therefore, we need a teaching materials that can assist students in understanding the concepts of physics, mathematical analysis and increase the interest of students towards learning Physics. One of the teaching materials that can be developed is based constructivist handout Basic Physics valid and practical. This type of research is the development of research (research and development) using the model proposed by Plomp. The stage of the research conducted in this study is limited to the initial investigation phase (preliminary research) and the design and realization phase (prototyping phase), and the phases of assessment (assessment phase). In the initial investigation phase, researchers conducted a preliminary analysis or identification of problems, needs analysis, analysis of the concept or content, and assessment of the necessary literature in learning. In the design and realization phase is to design the accompaniment formative evaluation for the validity and practicality. The research data was obtained through the validation handout sheet and questionnaire practicalities. The results of the validation and practicality test showed very valid handout produced by the average percentage of $92.55 \%$ and very practical with an average percentage of $82.25 \%$. Thus, the basic physics handouts produced can be used in learning. Keywords: Constructivist Learning, Handout, Validity, and the practicalities
\end{abstract}

\begin{abstract}
Abstrak
Ketersediaan bahan ajar untuk mata kuliah Fisika Dasar yang dapat mendukung terciptanya pembelajaran yang efektif dan interaktif di STKIP PGRI dirasakan masih kurang. Oleh karena itu, diperlukan suatu bahan ajar yang dapat membantu mahasiswa dalam memahami konsep fisika, analisis matematika dan dapat meningkatkan minat mahasiswa terhadap pembelajaran Fisika Dasar. Salah satu bahan ajar yang dapat dikembangkan adalah handout Fisika Dasar berbasis konstruktivis yang valid dan praktis. Jenis penelitian yang digunakan adalah penelitian pengembangan (research and development) menggunakan model yang dikemukakan oleh Plomp. Adapun tahap penelitian yang dilakukan dalam penelitian ini dibatasi pada fase investigasi awal (preliminary research) dan fase perancangan dan realisasi (prototyping phase), dan fase penilaian (assessment phase). Pada fase investigasi awal,peneliti melakukan analisis awal atau identifikasi masalah, analisis kebutuhan, analisis konsep atau isi materi, dan pengkajian literatur yang diperlukan dalam pembelajaran. Pada fase perancangan dan realisasi dilakukan perancangan yang diiringi formative evaluation untuk melakukan uji validitas dan kepraktisan. Data penelitian ini diperoleh melalui lembar validasi handout dan angket praktikalitas. Hasil validasi dan uji kepraktisan menunjukkan handout yang dihasilkan sangat valid dengan persentase rata-rata sebesar $92,55 \%$ dan sangat praktis dengan persentase ratarata $82,25 \%$. Dengan demikian, handout fisika dasar yang dihasilkan dapat digunakan dalam pembelajaran.
\end{abstract}

Kata Kunci: Pembelajaran Konstruktivis, Handout, Validitas, dan Praktikalitas 


\section{PENDAHULUAN}

Fisika dasar merupakan salah satu mata kuliah yang diajarkan di program studi Pendidikan Biologi STKIP PGRI Sumatera Barat. Mata kuliah ini bermanfaat untuk membentuk sikap kritis dan kearifan mahasiswa karena mereka akan dilatih untuk menganalisis dan menggunakan konsep fisika melalui perkuliahan. Selain itu, mata kuliah fisika dasar juga memberikan landasan fisika yang bertolak dari pengetahuan fisika yang telah diperoleh di SMA. Dalam mata kuliah ini, mahasiswa diharapkan dapat memahami dasar-dasar fisika dan dapat menggunakan formulasi fisika untuk memecahkan masalah fisika sederhana yang ditemukan di lingkungan dan menerapkan konsep fisika dalam bidang lain.

Pembelajaran fisika yang dilakukan diharapkan dapat menumbuhkan sikap berpikir kritis dan kemampuan analisis mahasiswa dalam menemukan konsep dan menyelesaikan permasalahan fisika yang mereka temukan. Dengan kata lain, mereka diharapkan mampu mengkonstruksi pengetahuan secara mandiri tentang topik-topik yang terdapat dalam mata kuliah Fisika Dasar. Melalui proses penemuan sendiri ini, mahasiswa akan lebih mampu memahami konsep yang dipelajari. Selain itu, kegiatan pembelajaran akan berjalan lebih efektif, interaktif, dan lebih menantang, serta tercapainya tujuan pembelajaran dengan lebih optimal.

Berdasarkan hasil pengamatan di lapangan dan tanya jawab terhadap mahasiswa yang telah mengambil mata kuliah fisika dasar, diketahui bahwa mahasiswa kurang memahami konsep fisika dasar. Hal ini disebabkan oleh kurangnya minat dan motivasi mahasiswa dalam mempelajari fisika. Selain itu, pembelajaran yang dilakukan kurang mendukung aktivitas dan partisipasi aktif dari mahasiswa.

Selanjutnya, bahan ajar yang digunakan dalam perkuliahan berupa buku teks. Secara keseluruhan, buku teks yang digunakan cukup bagus karena menyajikan aplikasi materi dan soal-soal yang bervariasi. Akan tetapi, materi yang disajikan terlalu padat dan kurang sistematis dengan urutan topik-topik perkuliahan fisika dasar. Hal ini menyebabkan mahasiswa kurang termotivasi untuk belajar mandiri dengan memanfaatkan buku tersebut, sehingga mahasiswa lebih cenderung menunggu penjelasan dari dosen. Dengan demikian, mahasiswa bersifat pasif dalam pelaksanaan proses perkuliahan.

Salah satu upaya yang dapat dilakukan untuk mengatasi masalah pembelajaran tersebut adalah dengan mengembangkan suatu bahan ajar yang dapat menunjang sikap aktif dan kritis mahasiswa dalam mengkonstruksi pengetahuan mereka secara mandiri. Bahan ajar tersebut hendaknya juga memotivasi mahasiswa untuk memanfaatkan sumber belajar yang tersedia di perpustakaan. Selain itu, bahan ajar yang dikembangkan juga harus sesuai dengan karakteristik mahasiswa. Salah satu bahan ajar yang dapat dikembangkan adalah handout.

Handout merupakan salah satu bentuk bahan ajar cetak yang dapat berisi pernyataan, uraian materi, bagan, pertanyaan, tugas, serta bahan referensi yang telah disiapkan oleh pembicara. Materi pada handout diambil dari beberapa literatur yang memiliki relevansi dengan materi yang akan diajarkan. Penggunaan handout dapat memotivasi mahasiswa untuk lebih aktif dalam kegiatan pembelajaran dan membantu mereka dalam memahami konsep-konsep yang dipelajari karena materi disajikan secara sistematis sesuai dengan materi perkuliahan.

Handout disusun berdasarkan kompetensi yang harus dicapai dalam suatu pembelajaran. Berdasarkan panduan pengembangan bahan ajar

(Depdiknas: 2008), ada beberapa langkah yang perlu dilakukan dalam menyusun handout. Langkah-langkah tersebut antara lain melakukan analisis kurikulum, menentukan judul handout sesuai dengan kompetensi dan materi yang akan dicapai, mengumpulkan referensi sebagai bahan penulisan, menggunakan kalimat yang singkat, padat, dan jelas dalam menulis handout, mengevaluasi 
hasil tulisan, dan menggunakan berbagai sumber belajar yang dapat memperkaya materi handout.

Penyusunan handout biasanya memuat beberapa unsur, seperti kompetensi dasar, ringkasan materi, soal-soal, dan sumber bacaan (Chairil: 2009). Penggunaan handout dalam pembelajaran dapat memberikan beberapa keuntungan. Menurut Davies dalam Chairil (2009), penggunaan handout dapat menghemat waktu pembelajaran, dapat digunakan sebagai pengganti catatan mahasiswa, memelihara kekonsistenan penyampaian materi di kelas, membantu mahasiswa mengikuti struktur pembelajaran dengan baik, dan membantu mahasiswa memahami pokok pembelajaran yang diberikan oleh dosen. Dengan demikian, penggunaan handout dalam pembelajaran dapat merangsang rasa ingin tahu mahasiswa dalam mengikuti pembelajaran, meningkatkan kreativitas mahasiswa, serta memelihara kekonsistenan penyampaian materi pembelajaran sesuai dengan perencanaan pembelajaran.

Salah satu pendekatan yang dapat digunakan untuk mengembangkan handout fisika dasar ini adalah pendekatan konstruktivis. Upaya ini diambil karena berdasarkan pengamatan di lapangan belum ditemukan handout fisika dasar yang dikembangkan berbasis konstruktivis.

Pembelajaran konstruktivis merupakan suatu kegiatan pembelajaran yang menekankan kepada proses pengembangan pengetahuan secara mandiri dan pengelolaan kemampuan berpikir mahasiswa dalam menemukan konsep. Hal ini sejalan dengan pendapat Chen (2003) yang menyatakan bahwa paham konstruktivis memandang belajar sebagai suatu proses pembentukan pengetahuan dengan pengembangan konsep dan pemahaman yang luas sebagai tujuannya.

Selanjutnya, Santyasa (2007) menjelaskan lima prinsip dasar yang melandasi pembelajaran konstruktivis. Prinsip-prinsip tersebut adalah meletakkan permasalahan yang relevan dengan kebutuhan mahasiswa, menyusun pembelajaran di sekitar konsep utama, menghargai pandangan mahasiswa, materi pembelajaran menyesuaikan terhadap kebutuhan mahasiswa, dan menilai pembelajaran secara kontekstual. Implikasi teori konstruktivisme dalam pembelajaran adalah mahasiswa melakukan proses aktif dan mengkonstruksi gagasannya menuju konsep ilmiah.

Menurut Riyanto (2010), terdapat beberapa hal yang harus diperhatikan oleh seorang pendidik yang menerapkan paham konstruktivis dalam pembelajaran, seperti mendorong mahasiswa untuk bertanya dan mengajukan pertanyaan satu dengan yang lainnya, dan mengajak mahasiswa terlibat dalam pengalaman yang mungkin bertentangan dengan hipotesis awal mereka dan kemudian mendorong adanya diskusi. Dalam pembelajaran konstruktivis setiap mahasiswa memiliki peranan yang lebih besar dalam pembelajaran. Dosen berperan sebagai guide atau sumber yang bertujuan untuk membangun lingkungan belajar agar mahasiswa dapat memahami informasi yang diperoleh melalui pemahamannya sendiri.

Dalam pelaksanaan pembelajaran konstruktivisme ada beberapa saran yang berkaitan dengan rancangan pembelajaran yang dikemukakan oleh Sidik (2008), antara lain memberikan kesempatan kepada mahasiswa untuk mengemukakan pendapatnya dengan bahasa sendiri, memberi kesempatan kepada siswa untuk berfikir tentang pengalamannya sehingga lebih kreatif dan imajinatif, mendorong siswa untuk memikirkan perubahan gagasan mereka, dan menciptakan lingkungan yang kondusif.

Prosedur pembelajaran berdasarkan konstruktivisme berupa memfasilitasi mahasiswa membangun sendiri konsep-konsep baru berdasarkan konsep lama yang telah dimilikinya (Indrawati: 2007). Ada lima fase atau tahapan dalam prosedur pembelajaran konstruktivisme, yaitu orientasi, penggalian ide, restrukturisasi ide, aplikasi ide, dan review perubahan ide. Orientasi dan penggalian ide merupakan proses untuk memotivasi siswa 
dalam mengawali proses pembelajaran. Selanjutnya, restrukturisasi ide meliputi ide, merombak ide dengan melakukan konflik terhadap situasi yang berlawanan, dan mengkonstruksi serta mengevaluasi ide yang baru. Aplikasi ide merupakan kegiatan menerapkan ide yang telah dipelajari. Kemudian, tahapan terakhir adalah review perubahan ide, yaitu mengadakan tinjauan terhadap perubahan ide tersebut.

Berdasarkan keutamaan pembelajaran konstruktivis, perlu dikembangkan bahan ajar yang menerapkan pendekatan konstruktivis. Bahan ajar yang dikembangkan handout fisika dasar berbasis konstruktivis. Dengan demikian, kegiatan pembelajaran yang dilaksanakan diharapkan lebih efektif dan interaktif.

\section{METODOLOGI PENELITIAN}

Penelitian yang dilakukan adalah penelitian pengembangan. Menurut Soenarto (2005), penelitian pengembangan adalah penelitian yang bertujuan untuk mengembangkan dan menghasilkan suatu produk berupa materi, media, alat atau strategi pembelajaran yang digunakan untuk menguji suatu teori. Model pengembangan handout berbasis konstruktivis ini menggunakan model pengembangan yang dikemukakan oleh Plomp (2010) yang terdiri dari fase investigasi awal (preliminary research), fase perancangan dan realisasi (prototyping phase), dan fase penilaian (assessment phase). Penelitian ini hanya dilakukan sampai fase kedua.

Pada fase investigasi awal, peneliti melakukan analisis awal atau identifikasi masalah, analisis kebutuhan, analisis konsep atau isi materi, dan pengkajian literatur yang diperlukan dalam pembelajaran. Analisis konsep bertujuan untuk menentukan isi dan materi pembelajaran yang dibutuhkan dalam pengembangan handout. Pada analisis konsep, peneliti melakukan identifikasi terhadap konsep esensial dari materi dinamika. Selanjutnya, dilakukan analisis terhadap karakteristik mahasiswa untuk menentukan model pengembangan handout yang akan beberapa tahap, yaitu klarifikasi terhadap

digunakan. Selain itu, peneliti juga melakukan kajian terhadap literatur yang tersedia.

Selanjutnya, pada fase perancangan dan realisasi dilakukan perumusan atau perancangan terhadap handout. Rancangan handout ini merujuk pada panduan pengembangan bahan ajar yang dikeluarkan oleh Depdiknas. Perancangan bahan ajar meliputi beberapa tahapan, yaitu mengkaji kesesuaian materi dengan kompetensi dasar yang terdapat dalam kurikulum, menentukan kedalaman materi dan ruang lingkup bahan ajar, menentukan urutan bahan ajar, menentukan jenis perlakuan yang akan diberikan terhadap bahan ajar, dan menentukan sumber materi pembelajaran. Pada tahapan ini, dilakukan penulisan, penelaahan dan pengeditan handout yang disusun. Perancangan handout dibuat sesuai dengan indikator yang ditetapkan dan berdasarkan format yang disesuaikan dengan kebutuhan peneliti.

Pada fase perancangan dan realisasi juga dilakukan formative evaluation. Alur desain untuk formative evaluation seperti ditunjukkan pada Gambar 1 di bawah ini.

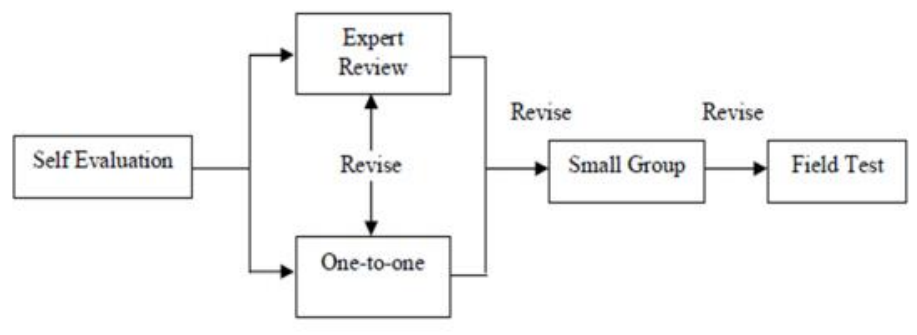

Gambar 1. Alur Desain Formative Evaluation (Tessmer: 1998)

Penilaian ini bertujuan untuk mengukur tingkat validitas dan praktikalitas handout yang dikembangkan. Pada fase ini dilakukan penilaian dan evaluasi oleh pakar terhadap 
handout yang telah dirancang. Pakar-pakar tersebut menilai validasi isi, konstruk, dan bahasa. Saran-saran dari para pakar digunakan sebagai acuan untuk merevisi handout yang dikembangkan. Bagian utama yang divalidasi adalah kesesuaian $\mathrm{KD}$, indikator, kebenaran konsep dan bahasa yang digunakan. Masukan dari validator digunakan untuk memperbaiki dan merevisi perangkat pembelajaran yang dikembangkan sehingga dihasilkan handout yang valid. Selanjutnya, dilakukan uji coba desain yang telah dikembangkan kepada mahasiswa dan dosen yang menjadi tester. Hasil dari uji coba ini digunakan untuk merevisi desain yang telah dibuat sampai dinyatakan valid dan praktis.

Instrument yang digunakan adalah lembar validasi dan angket praktikalitas. Uji coba produk dilakukan pada mahasiswa program studi Pendidikan Biologi STKIP PGRI Sumatera Barat tahun pelajaran 2014/2015 di semester 1 yang sedang mengambil mata kuliah Fisika Dasar.

Hasil uji validitas dan praktikalitas pada penelitian ini diperoleh dengan menggunakan persamaan berikut:

$$
V=\frac{X}{Y} \times 100 \%
$$

(dimodifikasi dari Riduwan, 2007:23).

Kategori validitas dan praktikalitas handout berdasarkan nilai validitas dan praktikalitas yang diperoleh dapat dilihat pada Tabel 1 .

Tabel 1. Kategori Validitas dan Praktikalitas handout

\begin{tabular}{cc}
\hline Interval & Kategori \\
\hline $0-20$ & Tidak valid/praktis \\
$21-40$ & Kurang valid/praktis \\
$41-60$ & Cukup valid/praktis \\
$61-80$ & Valid/praktis \\
$81-100$ & Sangat valid/praktis \\
\hline
\end{tabular}

(Dimodifikasi dari Riduwan, 2007:23)

\section{HASIL DAN PEMBAHASAN}

Pada fase investigasi awal dilakukan analisis konsep, analisis terhadap karakteristik mahasiswa, dan kajian terhadap literatur yang ada. Analisis konsep bertujuan untuk menentukan isi dan materi pembelajaran yang dibutuhkan dalam pengembangan handout. Pada analisis konsep, peneliti melakukan identifikasi terhadap konsep esensial dari materi dinamika. Dari hasil analisis, materi dinamika dibagi untuk tiga pertemuan. Pertemuan pertama membahas mengenai gaya dan macam-macam gaya. Pada handout kedua materi yang disajikan berkaitan dengan hukum Newton. Selanjutnya pada pertemuan ketiga, materi yang disajikan dalam handout adalah penerapan hukum Newton pada bidang datar, bidang miring, gerak vertikal, dan gerak melingkar.

Setelah melakukan analisis konsep, dilakukan analisis terhadap karakteristik mahasiswa untuk menentukan model pengembangan handout yang akan digunakan. Berdasarkan pengamatan yang dilakukan, dalam kegiatan pembelajaran mahasiswa cenderung menerima informasi yang diberikan dosen sehingga keaktifannya di kelas masih kurang dan mereka mengalami kesulitan dalam memahami materi yang dipelajari. Untuk itu, pengembangan handout perlu dilakukan secara sistematis sehingga dapat menuntun mahasiswa dalam mempelajari materi tersebut.

Berdasarkan analisis terhadap mahasiswa tersebut, maka handout berbasis konstruktivis sesuai dengan kondisi siswa. Dengan penggunaan perangkat pembelajaran yang dikembangkan dengan berorientasi pada pembelajaran konstruktivis, mahasiswa dimotivasi untuk membangun pengetahuannya sendiri. Selain itu, mereka juga dituntut untuk berpartisipasi aktif dalam segala kegiatan pembelajaran. Dengan demikian, diharapkan mahasiswa 
dapat memahami materi yang dipelajarinya dengan baik.

Selain itu, peneliti juga melakukan kajian terhadap literatur yang tersedia. Berdasarkan hasil survei, di perpustakaaan telah tersedia buku-buku fisika dasar. Akan tetapi, penggunaan buku tersebut masih belum optimal. Hal ini disebabkan oleh kurangnya minat mahasiswa untuk menggunakan literatur yang tersedia. Oleh karena itu, pengembangan handout dilakukan dengan memanfaatkan berbagai literatur yang ada di perpustakaan sehingga diharapkan mahasiswa dapat lebih termotivasi untuk memanfaatkan literatur yang tersedia.

Pada fase perancangan dan realisasi dilakukan perumusan atau perancangan terhadap handout. Perancangan handout meliputi beberapa tahapan, yaitu mengkaji kesesuaian materi dengan kompetensi dasar yang terdapat dalam kurikulum, menentukan kedalaman materi dan ruang lingkup bahan ajar, menentukan urutan bahan ajar, menentukan jenis perlakuan yang akan diberikan terhadap bahan ajar, dan menentukan sumber materi pembelajaran.

Kompetensi dasar yang dikembangkan dalam handout adalah memahami konsep dasar dinamika. Berdasarkan kompetensi dasar tersebut, materi yang dikembangkan dibagi menjadi tiga sub topik yaitu gaya dan macam-macam gaya, hukum newton, serta penerapan hukum Newton. Sumber yang digunakan untuk pembuatan handout diambil dari beberapa buku fisika dasar yang tersedia di perpustakaan. Selanjutnya, peneliti merancang handout berbasis konstruktivis yang memiliki beberapa fase atau tahapan meliputi orientasi dan penggalian ide, restrukturisasi ide, aplikasi ide, dan review perubahan ide.
Handout yang telah dirancang selanjutnya di evaluasi dan dinilai oleh pakar atau teman sejawat. Pakar-pakar tersebut menilai validasi isi, konstruk, dan bahasa. Saran-saran dari para pakar atau teman sejawat digunakan sebagai acuan untuk merevisi handout yang dikembangkan. Bagian utama yang divalidasi adalah kesesuaian $\mathrm{KD}$, kebenaran konsep dan bahasa yang digunakan. Masukan dari validator digunakan untuk memperbaiki dan merevisi handout yang dikembangkan sehingga dihasilkan handout yang valid.

Selanjutnya dilakukan validasi terhadap handout yang telah dibuat. Berdasarkan hasil validasi, dilakukan analisis untuk melihat kekurangan dari handout yang telah dirancang. Kemudian dilakukan revisi terhadap handout tersebut berdasarkan saran dari validator.

Berdasarkan hasil validasi diperoleh nilai $92,55 \%$ yang menunjukkan bahwa handout yang dikembangkan telah dinyatakan valid oleh para pakar. Dengan demikian dapat dikatakan bahwa handout berbasis konstruktivis yang dikembangkan dapat digunakan dalam menciptakan kegiatan pembelajaran yang interaktif, inspiratif, menyenangkan, menantang, memotivasi peserta didik untuk berpartisipasi aktif.

Selanjutnya dilakukan uji praktikalitas terhadap handout. Uji praktikalitas dilakukan dengan menggunakan angket praktikalitas dosen dan mahasiswa. Berdasarkan hasil analisis terhadap angket respon dosen diperoleh nilai praktikalitas sebesar $82,5 \%$ dengan kategori sangat praktis. Sementara hasil analisis angket respon mahasiswa terhadap handout diperoleh nilai praktikalitas sebesar $82 \%$ dengan kategori sangat praktis dengan kategori sangat praktis. 
Adapun contoh handout yang dirancang dapat diamati pada Gambar 2.

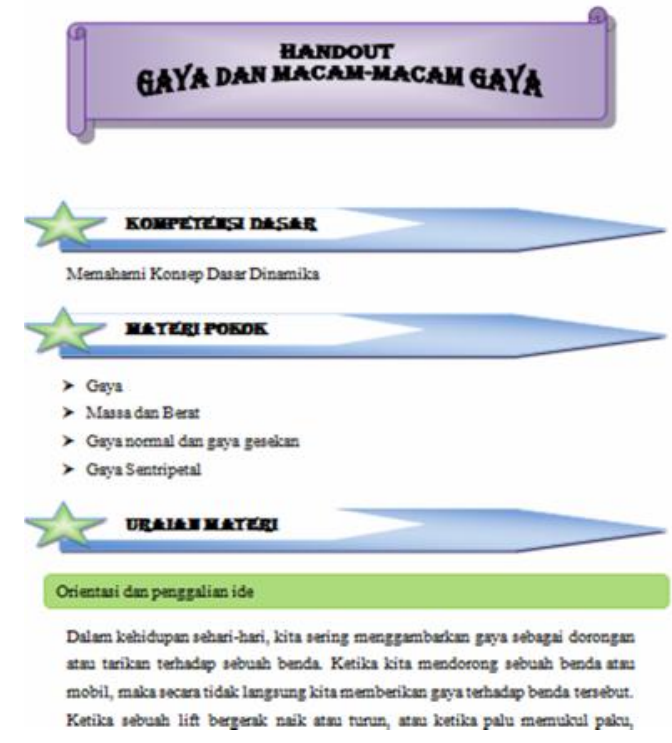

Gambar 2. Contoh Handout Berbasis Konstruktivis

Berdasarkan Gambar 1 bagian inti dari handout menunjukkan fase-fase dalam pembelajaran konstruktivis. Fase-fase ini meliputi fase orientasi dan penggalian ide, restrukturisasi ide, aplikasi ide, dan review perubahan ide. Selain itu, handout juga dilengkapi dengan petunjuk penggunaan.

\section{KESIMPULAN}

Berdasarkan pengembangan dan uji coba yang telah dilakukan, diperoleh kesimpulan bahwa hasil validasi dari para validator menunjukkan handout fisika dasar berbasis konstruktivis yang dikembangkan sudah valid. Selanjutnya, hasil analisis terhadap angket respon dari dosen dan mahasiswa menunjukkan bahwa handout fisika dasar berbasis konstruktivis praktis untuk digunakan. Handout ini dapat digunakan sebagai salah satu bahan ajar dalam pelaksanaan kegiatan pembelajaran, sehingga membuat mahasiswa berpartisipasi aktif dan mampu berpikir kritis.

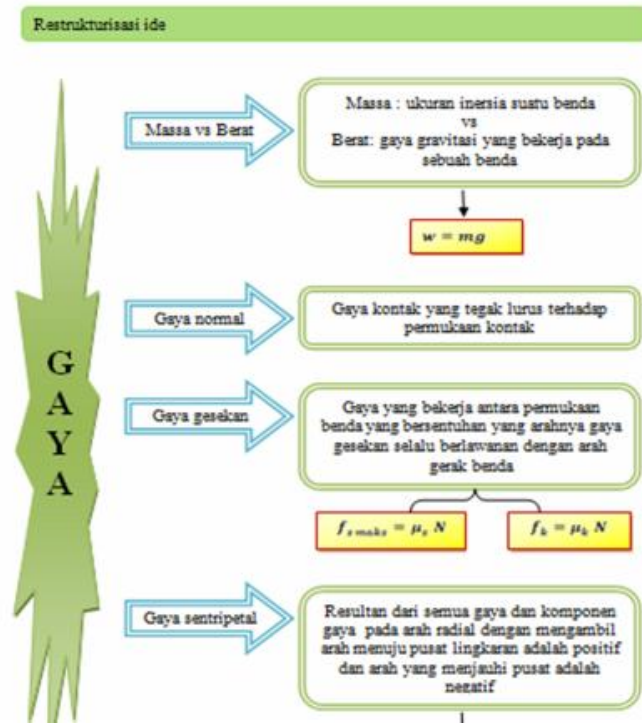

\section{UCAPAN TERIMA KASIH}

Penulisan dan penyelesaian makalah ini, tidak terlepas dari bantuan dan dorongan dari berbagai pihak. Oleh karena itu, penulis menyampaikan terima kasih yang tulus kepada dosen program studi Pendidikan Fisika dan mahasiswa program studi Pendidikan Biologi STKIP PGRI yang telah meluangkan waktu dalam memberi bantuan serta motivasi kepada penulis hingga selesainya pelaksanaan penelitian dan penulisan makalah ini.

\section{DAFTAR PUSTAKA}

[1] Depdiknas. 2008. Panduan Pengembangan Bahan Ajar. Jakarta : Direktorat Pembinaan Sekolah Menengah Atas.

[2] Chairil. 2009. Media Handout. (http://chai-chairil.blogspot.com, diakses 30 November 2013)

[3] Chen, C. (2003). A Constructivist Approach to Teaching: Implications in Teaching Computer Networking. Information Technology, Learning, and Performance, (Online), Vol.21, 
No. 2, (http://www.osra.org, diakses 14 September 2011).

[4] Santyasa, I W. 2007. "Model-model Pembelajaran Inovatif". Makalah disajikan dalam pelatihan tentang Penelitian Tindakan Kelas bagi GuruGuru SMP dan SMA di Nusa Penida, Nusa Penida, 29 Juni-1 Juni

[5] Riyanto, Y. 2010. Paradigma Baru Pembelajaran. Jakarta: Prenada Media Group.

[6] Riduwan dan Sunarto. (2007). Pengantar Statistika untuk Penelitian : Pendidikan, Sosial, Komunikasi, Ekonomi, dan Bisnis. Bandung: Alfabeta

[7] Sidik, M. H. 2008. "Penerapan Model Pembelajaran Konstruktivisme untuk Meningkatkan Pemahaman Siswa Mengenai Energi Gerak di Kelas III SD Negeri I Cilengkranggirang Kecamatan Pasaleman Kabupaten Cirebon". Skripsi tidak diterbitkan. Sumedang: Program S1 Pendidikan Guru Sekolah Dasar UPI.

[8] Soenarto. (2005). Metodologi Penelitian Pengembangan untuk Meningkatkan Kualitas Pembelajaran (Research Method The Improvement of Instruction Methodology). Makalah 14 Agustus di Denpasar. PPTK dan KPT Depdiknas 
